\title{
Ina sua: The traditional Food Fermentation from Teon Nila Serua, Central of Maluku, Indonesia
}

\author{
Cassandra Betsy Persulessy ${ }^{1 *} \mathbb{B}$, Endang Kusdiyantini ${ }^{1}$, Rejeki Siti Ferniah ${ }^{2}$, Tri Winarni Agustini ${ }^{3}$ and \\ Anto Budiharjo ${ }^{2,4^{*}}$
}

\begin{abstract}
Traditional fermented food as a special delicacy is one of the elements of culinary diversity found in many regions of Indonesia. This type of food is closely related to the customs and surrounding environment, displaying the characteristics of each region and ethnicity. Maluku is one of the regions located in Eastern Indonesia. Ina sua is a simple and traditional fermented food made from fish using salt as a basic ingredient, commonly eaten at a variety of traditional events in Central Maluku, especially in Teon Nila Serua (TNS). Ina sua is made to be stored and consumed during a time when fish is not available and when there are community activities such as birthdays and traditional events. In making Ina sua, fish are salted with salt granules and stored for a certain time. Therefore, this food is famous for its unique taste produced by the fermentation component. In this article, the origin of Ina sua, its method of preparation, and the scientific perspectives surrounding it are discussed.
\end{abstract}

Keywords: Ina Sua, Traditional fish food fermentation, Central of Mollucas

\section{Introduction}

Traditional foods are one of the elements of culture and identity of the community in certain region. The type of food also depends on the resources available in the area. Ina sua is one example of a typical food in Maluku. Indonesia has many traditional fermented foods, each with a different name and manufacturing process.

Fosh is one of the most abundant and desirable sea products is fish. In the Southeast Asian region, people obtain $60-70 \%$ of their protein from fish. Moreover, fish is an inexpensive and abundant nutritious food. Fish is high in protein, fat, vitamins, and minerals which are beneficial to human health.

\footnotetext{
* Correspondence: cassieersulessy22@gmail.com;

anto.budiharjo@fulbrightmail.org

${ }^{1}$ Department of Biology, Faculty of Science and Mathematics, Diponegoro

University, J. Prof. Sudharto SH, Semarang 50275, Indonesia

${ }^{2}$ Biotechnology Study Program, Faculty of Science and Mathematics,

Diponegoro University, J. Prof. Sudharto SH, Semarang 50275, Indonesia

Full list of author information is available at the end of the article
}

The people of Maluku consume various types of fish as a source of protein. In Teon Nila Serua (TNS), Central Maluku, people apply the salting technique in anticipation of a lack of protein sources. Preservation of fish by salting is an ancient technology. This method of preservation is still popular in many developing countries because of its simplicity and low cost. The product of this process is called Ina sua.

Ina sua is a fermented fish product made by people of Teon Nila Serua (TNS) in Central Maluku, Indonesia. They make this fermented fish to anticipate the gap time when fisherman cannot go out to sea [1]. Ina sua is a fermented fish in salt solution that is often called wet salt fish [2]. It is a spontaneous fermentation product, where the fish is not dried but immersed in a salt solution.

People in TNS have their own ways of enjoying Ina sua. Some people consume Ina sua with rice, cassava, and sweet potatoes, and others eat it with complementary traditional ingredients such as a Palm Plant called "Sageru." Sageru is derived from fermentation of sugar

(c) The Author(s). 2020 Open Access This article is licensed under a Creative Commons Attribution 4.0 International License, which permits use, sharing, adaptation, distribution and reproduction in any medium or format, as long as you give appropriate credit to the original author(s) and the source, provide a link to the Creative Commons licence, and indicate if changes were made. The images or other third party material in this article are included in the article's Creative Commons licence, unless indicated otherwise in a credit line to the material. If material is not included in the article's Creative Commons licence and your intended use is not permitted by statutory regulation or exceeds the permitted use, you will need to obtain permission directly from the copyright holder. To view a copy of this licence, visit http://creativecommons.org/licenses/by/4.0/ 


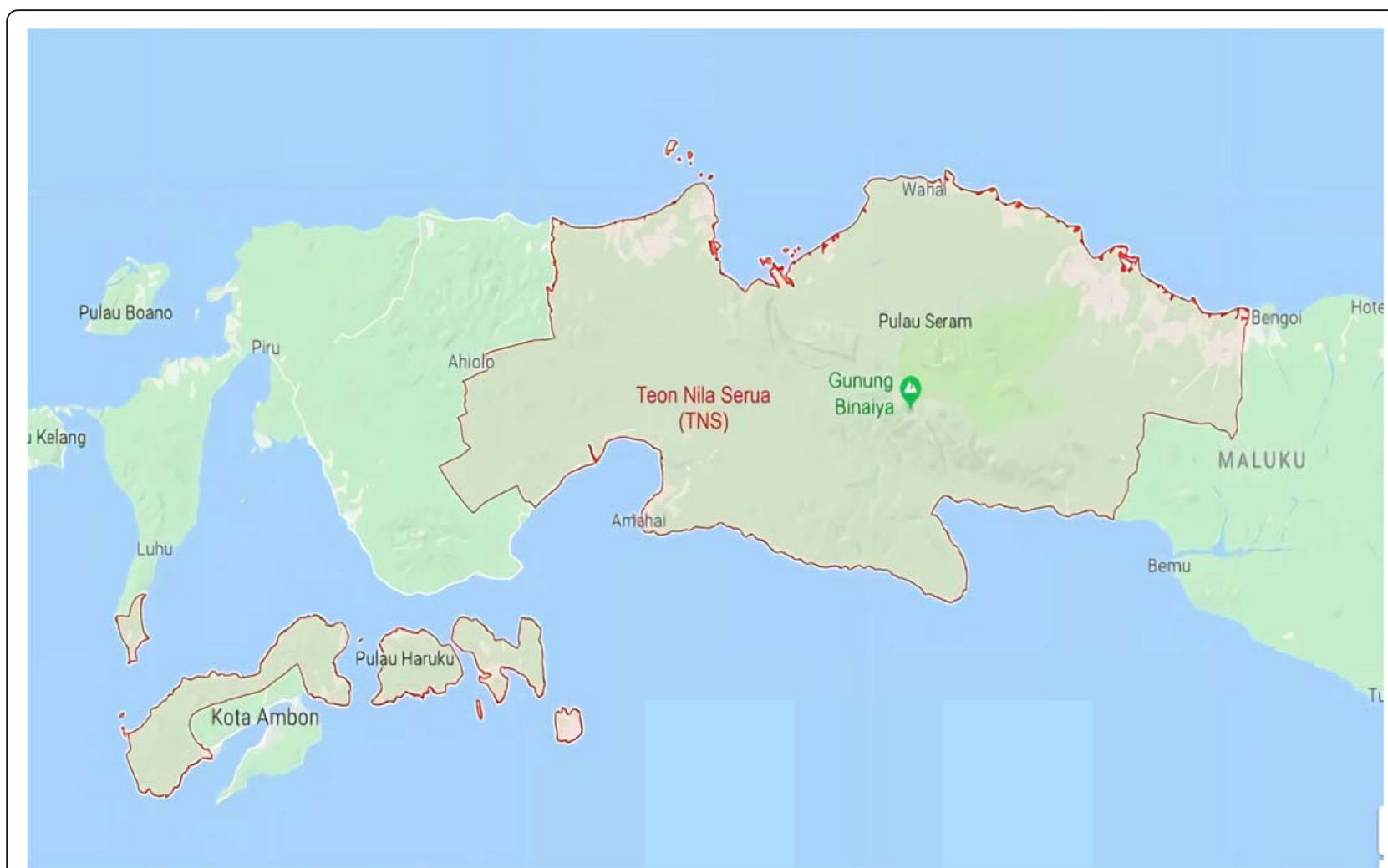

Fig. 1 Map of Teon Nila Serua. Teon Nila Serua is located in Central Maluku, Indonesia, especially on Seram Island. On the map, Teon Nila Serua is marked with red writing. Source: dailyvoyagers.com

palm plants, and the sucrose contained in the sap will be converted into alcohol and then turned into vinegar acid. Sageru is derived from fermentation of sugar palm plants, and the sucrose contained in the sap will be converted into alcohol and then turned into vinegar. Teon Nila Serua (TNS) is an ethnic group that dominates the population in Seram Village, Mollucas, Indonesia (Fig. 1).

Ina sua is mostly consumed as a daily menu of the community, especially when the bad weather restricts the fisherman to catch the fish. Ina sua is mostly consumed as a daily menu item in the community, especially when inclement weather prevents fisherman from catching fish. However, Ina sua is also widely consumed in various traditional ceremonies, such as Christmas Day and birthdays, especially at TNS. According to the Village Head, it has become a habit for the community to make Ina sua as an everyday dish and for certain events.

This is the first review to describe Ina Sua as a fermented food. This is because the uniqueness of Ina sua as a traditional food made by fermentation can be explained scientifically; therefore, more original articles than review articles have been written about is. This review has been written to explain the origins of Ina Sua, its presentation in the tradition of the TNS community, and the features of Ina Sua from a scientific perspective.

\section{Main text}

The origin of Ina sua salted fish in Teon Nila Serua (TNS) Salted fish is a food ingredient made from preserved fish meat by adding a large quantity of salt. With this method of preserving fish meat that usually rots in a short time, fish can be stored at room temperature for a period of months, although usually it must be closed tightly. In Indonesia, salted fish is generally made in the form of dried salted fish. Therefore, the salting process is always followed by a drying process. The most common drying process is done by direct sun.

Ina sua is a traditional product of wet salt fish fermentation produced by TNS Communities in Central Maluku, Indonesia [3]. The TNS people call this food by various names, for example In manna by the Teon community, Ina sua by the Nila community, and Ina skua by the Serua community. Ina sua comes from the word Ina, which means "fish" and sua, which means "salty". Ina Sua has a distinctive aroma due to ongoing fermentation and also because of the compounds present in the ingredients.

Ina sua is often served as food that must be available when there is family event. This event is usually only for silaturahmi or when there are other celebrations. Maluku people often call it "Kumpul Basudara." This 
tradition is limited to silaturahmi between families. Ina sua is served as a complementary meal during the event. Ina sua is served as a complementary meal during the event. Maluku people, especially TNS, have strong traditional and family events in the community. There are no specific events in the community other than family events because the most important tradition of Maluku is about family.

Ina sua is a fermented fish in a salt solution that is frequently called wet salt fish [2]. This method of salting is used by the TNS community to make Ina sua of various fish species, both large and small, and using salt in the form of crystals (Fig. 2). The salt used by the community to make Ina sua is also traditionally made by drying sea water. Beside demersal fish, coconut sap (Sageru) is also added to the Ina sua fermentation to extend the shelf life of this product to more than a year. In addition, people also often use additional ingredients known as Sageru (Fig. 3). Sageru is also made traditionally using basic coconut ingredients. Ina sua is also one of the traditional ethnic foods from the community because it is not produced in other communities in Indonesia and the surrounding Moluccas, only in the Teon Nila Serua community. So, the fermented food Ina sua may be concidered as a local ethnic food.

In general, lactic acid bacteria (LAB) play a dominant role in fish fermentation [4]. Fermentation can be carried out in two ways, spontaneously and nonspontaneously. Spontaneous fermentation is a fermentation process in which no starter or yeast is added, while non-spontaneous fermentation is a fermentation process involves the addition of a starter or yeast [5]. Microorganisms will grow and develop actively and turn fermented materials into the desired products of the fermentation process.

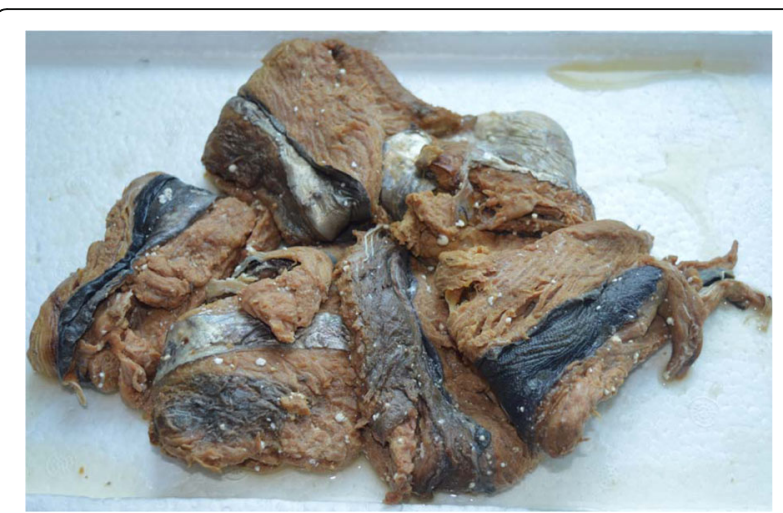

Fig. 3 In a sua is a traditional fermented food from Central Maluku. In a sua is usually used as a complementary food because it is made from fish. Ina sua is often found in community events. After the manufacturing process, Ina sua is kept put in a tightly closed. Ina sua after the manufacturing process can be consumed after being stored for 1 week and can even be consumed after being stored for 1 year

The fermentation process that occurs in fish is a biological or semi-biological decomposition process of complex compounds, especially proteins, into simpler compounds under controlled conditions. During the fermentation process, protein will be hydrolyzed into amino acids and peptides, then the amino acids will decompose further into other components that contribute to the flavor of the product.

Fish fermentation, which is a biological or semibiological process, can be distinguished into the following four groups:

a. Fermentation uses high salt levels, for example, peda, fish sauce, terasi, bekasam, and Ina sua.

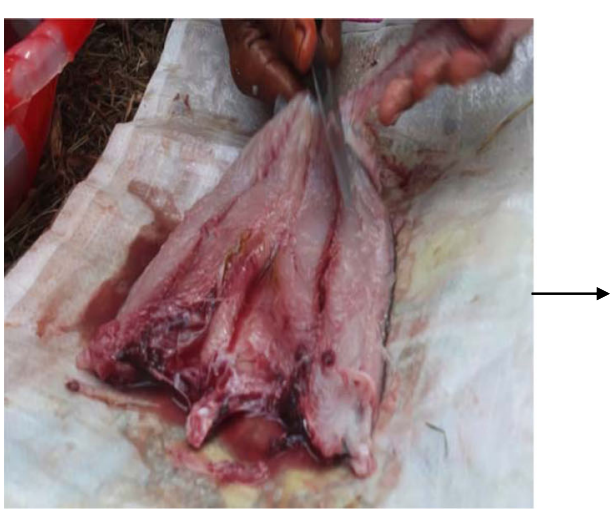

(a)

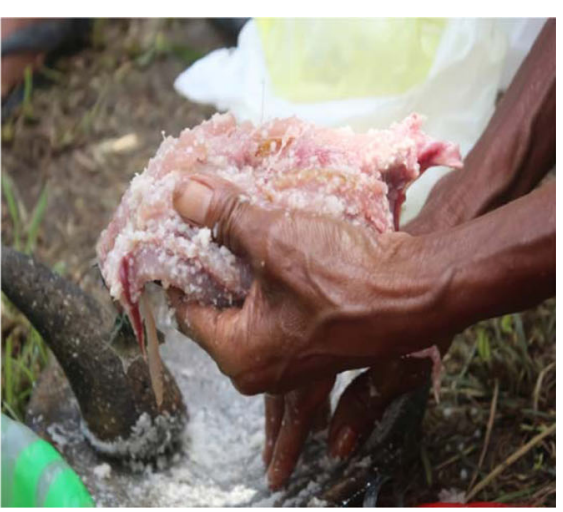

(b)

Fig. 2 The process of making Ina sua. The manufacturing process is very simple, namely, fish mixed with salt. The function of salt is that the stored Ina Sua can last for a long time. Besides simple, the process of making Ina Sua is also very traditional. a Fish are cut and cleaned. $\mathbf{b}$ Salt is mashed and smeared in the body of the fish 
b. Fermentation uses organic acids, for example, making fish silage by adding propionic acids and formatting.

c. Fermentation uses mineral acids, for example, in making fish silage using strong acids.

d. Fermentation uses bacteria, for example, in the manufacture of bekasam and chao teri.

\section{The flavor of Ina sua from a scientific perspective}

\section{Fish}

As people become increasingly aware of the connection between food and good health, consumers are recognizing that fish and shellfish are nutritious and wholesome foods. They are perceived as an excellent source of high quality protein, containing lipids with high levels of unsaturated fatty acids, and perhaps contributing to the enhancement of human health by reducing the risk of cardiovascular disease. A meta-analysis of observational studies assessing fish consumption and its association with coronary heart disease (CHD) mortality found that individuals who consumed fish once a week had a $15 \%$ lower risk than those who did not consume fish [6].

Fish are not only omega-3 fatty acid compounds but also protein. The protein content in fish meat reaches $17-22 \%$, with an average of $19 \%$, while cooked tuna contains $30 \%$ protein. These proteins function as structural elements of cells, enzymes in membranes, hormones and carriers. In terms of nutrition, protein is a source of energy and amino acids, which are important for cell growth and repair.

So far, fish are known as an inexpensive source of protein. Protein from fish is a good source of functional and nutritional aspects to meet human nutritional needs. The functional properties of proteins are defined as physicochemical characteristics and calculation of changes in food systems during preparation, processing, storage, and consumption. Apart from being a source of protein, fish is source of bioactive peptides. Bioactivepeptide compounds are found in fish meat from various species [7]. Humans need protein from plant and animal tissues as a source of nitrogen. The recommended daily intake (RDI) for protein is $0.8 \mathrm{~g} / \mathrm{kg} /$ day, but studies suggest that a slight increase in this recommendation to $1.0-1.3 \mathrm{~g} / \mathrm{kg} / \mathrm{day}$ could reduce the muscle loss associated with age [8].

Protein compounds in marine organisms consist of a series of bioactive peptides, which can have physiological effects in the body. Bioactive peptides usually consist of 3-20 amino acids, and the bioactive activity of these peptides depends on the content of the amino acids and their composition [9]. These peptides can regulate important bodily functions through their myriad activities, including antihypertensive, antimicrobial, antithrombotic, immunomodulatory, opioid, antioxidant, and mineral binding functions [10].
Fish is one food that has a fairly complete nutritional composition. Fish is richer in fat, vitamins and minerals. Fish meat contains vitamins, such as vitamin A, which is very beneficial for eye health and as an antioxidants. Vitamin D, which functions in calcium metabolism and bone growth; Vitamin B6, which is involved in the metabolism of amino acids and fats, preventing anemia and nerve damage; and Vitamin B12, which acts in the formation of red blood cells and fat metabolism and protection of the heart. In addition to protein, fat, and vitamins, fish also contains several minerals such as iron, which functions in the formation of red blood cells; iodine, which is associated with the health of the thyroid gland and prevents swelling of the thyroid gland; selenium, which acts as an antioxidant; zinc, which functions as a cofactor for enzymes and hormones; and flouride, which is related to nutritional health.

In general, some minerals and other elements are present in larger quantities in marine fish and other organisms than in land animals. Selenium and iodine are two such elements. Consumption of selenium can inhibit the growth of cancer. A report from the American Institute of Cancer Research (AICR) states that selenium can prevent skin cancer and lung cancer. The presence of selenium in the body has an impact on heart and nerve diseases [11]. Functional compounds found in the fish above have been widely applied in food and beverage products. Increased consumer awareness of health, has increase the popularity of functional foods. Some of these functional foods utilize functional compounds from fish and other marine animals.

\section{Salt}

Salt is a white, crystalline solid composed mainly of sodium chloride (> 80\%) and containing smaller amounts of other compounds such as magnesium chloride, magnesium sulfate, calcium chloride, and others. Salt has hygroscopic characteristics, which means it absorbs water easily, its bulk density is $0.8-0.9$, and its melting point is at a temperature of $801{ }^{\circ} \mathrm{C}$. Salt is obtained in three ways: evaporation of seawater by sunlight, rock salt mining, and brine well water [12].

Sodium $(\mathrm{Na})$ is one of the main alkaline elements and is an important cation in water. Almost all natural water contain sodium, with levels varying from $1 \mathrm{mg} / \mathrm{l}$ to thousands of milligrams per liter. Sodium levels in sea waters can reach $10,500 \mathrm{mg} / \mathrm{l}$ or more. Sodium chloride, also known as salt and table salt, is an ionic compound with the formula $\mathrm{NaCl}$. Sodium chloride is generally a clear and odorless solid and can dissolve in glycerol, ethylene glycol, and formic acid, but it does not dissolve in $\mathrm{HCl}$. $\mathrm{NaCl}$ is the main ingredient in table salt and is usually used as a spice and food preservative, sodium chloride is sometimes used as an inexpensive and safe drying 
material because it has hygroscopic properties, making salting an effective method of food preservation.

Salt is usually added in the processing of certain foods. The addition of salt aims to obtain specific conditions that allow salt-resistant enzymes or microorganisms (halotolerant) to react to produce food products with certain characteristics. A high salt level causes microorganisms that are not resistant to salt to die. This selective condition allows salt-resistant microorganisms to grow. Under certain conditions, added salt functions as a preservative because high salt levels produce high osmotic pressure and low water activity. This extreme condition causes most microorganisms to to be inviable. Processing with salt is usually carried out in combination with other treatments such as fermentation and enzymatic methods. Examples of food processing with salt are pickle processing and the manufacture of fish sauce, dried meat, and cheese.

In the tradition of the TNS community, food is usually preserved with homemade salt. The method of salt making is common knowledge using evaporation with the help of solar energy (solar evaporation). The process of making salt from seawater basically consists of concentration process (by evaporating the water) and separation of the salt (by crystallization). If all the substances contained in seawater are crystallized, the salt it will consist of a mixture of various substances, not only sodium chloride but also some unwanted substances (impurities).

\section{Sugar palm plant (Sageru)}

Palm trees (Arenga pinnata, Merr) are distributed throughout most of Indonesia and are a source of income for farmers in the areas of North Sumatra, West Sumatra, Bengkulu, West Java, Banten, South Kalimantan, East Kalimantan, South Sulawesi, North Sulawesi, Maluku, Irian Jaya, and East Nusa Tenggara [13]. Aren is a commodity of local Maluku, which has the potential for development because all parts of this plant can be processed into various products of economic value, such as young fruit can be processed into foliage; leaf bones can be used as a broom stick; the starch is used as a material for making vermicelli and noodles; palm fiber can be used as a rope, brush, or other cleaning tool; and sap from the results of tapping can be processed into vinegar, palm sugar, and palm wine. The palm tree, resembling a coconut tree (Coccus nucifera), is a multifunctional plant, and all parts of the plant can be used for human needs. Palm trees are one of the ecosystem's balancing plants and important in rural ecology.

The sugar palm plants is not only used for its leaves, fruits, and stems, but for its sap, which has a high economic value. Sap is basically water that comes out of palm or coconut flowers. Nira is a natural drink that tastes sweet because it contains glucose. Nira is a fertile medium for the growth of microorganisms, so it can undergo natural fermentation. Nira fermentation is carried out in a container that is open for 8 days and will turn into vinegar [14]. The sour taste of vinegar is caused by its acid content. According to [14], sap that has just dripped from a flower cage has a neutral $\mathrm{pH}$, but the influence of ambient conditions causes palm sugar to be easily contaminated and fermented so that the sweet tasting sap will quickly turn into acid.

In Maluku, Nira is the basic ingredient used making Sageru, palm sugar, brown sugar, vinegar, yeast substitute material in making cakes, and sopi and is relied upon as one source of income the community. In areas outside of Maluku, palm sap from the results of tapping not only processed into household needs but has also been processed into bioethanol as a substitute fuel for gasoline which has a higher economic value. The example above illustrates that sugar palm has potential not only as a source of income for the people in Maluku but also for the development of bioethanol going forward.

Sageru is a sweet liquid obtained from the juice of stems and latex bunches of plant flowers from the palm family (palm) such as palm and coconut (Fig. 4). Sageru is one of the supplements used by the community to make Ina sua. Sageru is obtained by tapping the mayang in the morning or evening and collecting the liquid in the afternoon or morning. Based on the customs of the community, Sageru is usually used to extend the shelf life of Ina sua. Sageru is best used soon after being tapped and may not be left out overnight because to do so will change the taste. This change in taste is due to the presence of bacteria that convert sugars to acids and is followed by a change in the amount of yeast in the sap used because the yeast will undergo succession if the substrate contains acid. Succession is a change in microbial composition as the fermentation time increases. The fermentation process in roomie (Nira) can take

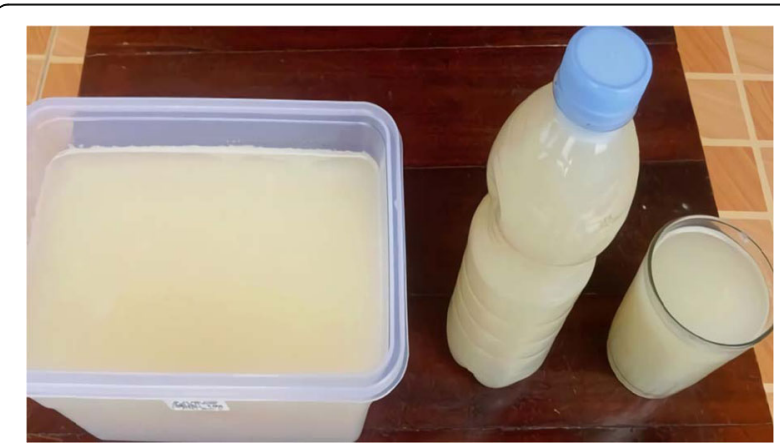

Fig. 4 Sageru from Maluku, Indonesia. It is one of the traditional characteristics of the Maluku people. Produced from the results of the sap tree and then stored so that it becomes acid and often stored in a bottle. Some people often make Sageru as an addition to fermentation in Ina Sua. So it can be stored longer 
place in a matter of hours. The microbes that grow further form acetic acid, which changes the taste of the sap due to the presence of bacteria, yeast, and lactic acid; this process called fermentation.

Sageru is a type palm sap that is obtained by tapping the male and female flowers of the palm tree. Palm juice can be made into drinks or produced into sugar (brown sugar). The sap has a sweet taste because it contains sugar. The sap in a fresh state is colorless, odorless, fragrant, and sweet, and the degree of acidity $(\mathrm{pH})$ is around 6.0-7.0. The sap generally has a high sugar content, which is around $7.5-15 \%$. The main sugar making up Nira is sucrose, which is in the range of $13-17 \%$. The sap also contains glucose and fructose but in very small quantities [13].

\section{Safety of traditional fermented foods}

Indonesia has many traditional fermented foods including salted vegetables, bekasam, and tempoyak. Bekasam is a food made from fish and rice. Tempoyak is made from durian fruit. Everything is made through a fermentation process, traditionally in a state of high salinity, and becomes a specialty food in each region.

Food can be considered eligible if meets three main criteria, namely, safe for consumption, nutritious, and delicious. Currently, food is also expected to meet the fourth condition, which is that it has medicinal properties. Safe means it does not contain anti-nutritional compounds. Nutritious means that the food eaten can supply substances needed by the body, such as carbohydrates, lipids, protein, vitamins, and minerals. Meanwhile, the taste of food is very important for a food to have a relationship with consumers. A food will provide added value if it is beneficial to human health because it contains functional compounds that have medical value, such as anticarcinogenic, antioxidant, and antimicrobial properties. Some foods are believed to meet such criteria, including fermented foods.

Traditional fermentation of fish is no longer used only to preserve foods, but many also produce nutrients. Biologically active substances are derived from protein degradation during fermentation and has been associated with several beneficial biological properties [15]. During the fermentation process, macromolecules such as proteins and carbohydrates are hydrolyzed to amino acids and simple sugars, which increase the nutritional value and form compounds contributing to flavor. After the fermentation process, the nutritional value, flavor, and texture improve. Lactic acid bacteria found in fermented products also produce bacteriocin compounds, which can repress pathogenic microbes such as fungi, so the possibility of growing harmful microbes can be avoided. This provides a safety element for fermented foods, for example, in the form of a fermentation product known to act as an anti-carcinogen [16].

The various types of fermented products in Indonesia have great potential to be studied and further developed to become functional foods and as raw materials for supplements/medicines. This will be able to increase the negative image of traditional products as food that is not much in demand by the public. In addition, the traditional fish products made from fermented fish contain a million benefits from the formation of various bioactive components beneficial to human health. Several studies have proven that the products are not only safe for consumption but also nutritious for health. This is because during the fermentation process, some anti-nutritional and toxic compounds can be reduced or converted into useful compounds. Hence, fermented foods are safe for consumption and even contain specific functional compounds that regulate the metabolic processes of other compounds so that the digestive process improves. The existence of bioactive components and probiotics produced from some traditional fermented fishery products has the potential for further development. This shows that fermentation produces organic substances that are beneficial to human health as a functional food or supplement.

Besides having benefits nutritional, functional food has benefits for maintaining body health. Functional food must meet the requirements of sensory acceptable consumers, can be consumed every day without side effects, can prevent or reduce symptoms and certain diseases, or maintain a healthy body. Functional foods can be natural due to the addition of bioactive components into food. In fermented fishery products, bioactive components are formed naturally during the fermentation process. Therefore, naturally fermented fishery products have functioned as functional foods. However, the activity of bioactive components in fish fermentation products is highly dependent on the processing methods. Some peptides cannot withstand high temperature heating for long periods. Therefore, proper processing methods are needed to minimize damage to bioactive components in fish fermentation products [15].

\section{Conclusion}

Ina sua has become part of the ethnic food for the Maluku people, especially the TNS community (Teon Nila Serua). Ina sua is referred as an ethnic food because it is only available in the Maluku region. Although there is no specific history of Ina sua in Indonesia and even in Maluku, the people of Maluku have accepted Ina sua as a typical food from Maluku. For them, Ina sua plays an important role in community events. In addition, Ina sua is also a source of food and income for many people, especially when it is sold to other communities outside 
the TNS area. Ina Sua is stored for years by the community so that it can be used later when needed either for certain events or to overcome shortage a of fish. Ina Sua has a distinctive aroma that comes from continuous fermentation and also from compounds in the ingredients. In addition to the aroma and taste, Ina Sua also has several compounds that are considered beneficial to health because it can inhibit pathogenic bacteria. To increase production, the production process must be developed so that it can be packaged properly to attract people's attention.

\section{Acknowledgements}

The authors would like to thank for all the people in Teon Nila Serua for giving chance to know about the traditional food from the Teon Nila Serua (TNS) Community. The authors would also like to thank Diponegoro University for providing RPIBT grant.

\section{Authors' contributions}

The authors read and approved the final manuscript.

\section{Funding}

RPIBT grant number 387-03/UN7.P4.3/PP/2018-Diponegoro University, Indonesia

\section{Availability of data and materials}

Not applicable.

\section{Competing interests}

The authors declare that there are no competing interests.

\section{Author details}

'Department of Biology, Faculty of Science and Mathematics, Diponegoro University, Jl. Prof. Sudharto SH, Semarang 50275, Indonesia. ${ }^{2}$ Biotechnology Study Program, Faculty of Science and Mathematics, Diponegoro University, Jl. Prof. Sudharto SH, Semarang 50275, Indonesia. ${ }^{3}$ Department of Fisheries, Fisheries and Marine Science Faculty, Diponegoro University, Jl. Prof. Sudharto SH, Semarang 50275, Indonesia. ${ }^{4}$ Molecular and Applied Microbiology Laboratory, Central Laboratory of Research and Service Diponegoro University, Jl. Prof. Sudharto SH, Semarang 50275, Indonesia.

Received: 26 December 2019 Accepted: 8 May 2020

Published online: 08 July 2020

\section{References}

1. Mahulette, F., Mubarik, N. R., Suwanto, A., \& Widanarni. (2016). Isolation and characterization of lactic acid bacteria from Ina sua. Journal of Tropical Biodiversity and Biotechnology, I(2), 71-76.

2. Nendissa SJ. Addition effect Pediococcus acidilactic F11 as startert culture to quality salty fish (Ina sua) bae (Lutjanus malabaricus). Ekosains. 2013;2:39-46.

3. Nara S, ljong FG, Suwetja IK, Onibala H. Ina sua, a fermented salted fish product from Central Mollucas. Aquatic Science and Management. 2013;1: $160-4$.

4. Noonpakdee W, Jumriangrit P, Wittayaom K, Zendo J, Nakayama J, Sunamata $\mathrm{K}$, et al. Two-peptide bacteriocin from Lactobacillus plantarum PMU 33 strain isolated from som-fak, a Thai low salt fermented fish product. Asia Pasific Journal of Molecular Biology and Biotechnology. 2009;17:19-25.

5. Suprihatin. Teknologi Fermentasi. Subaraya: UNESSA Pres; 2010.

6. He K, Song Y, Daviglus ML, Liu K, Horn LV, Dyer AR, et al. Accumulated evidence on fish consumption and coronary heart disease mortality. Circulation. 2004;109:2705-11.

7. Kadam SU, Prabhasankar P. Marine food as functional ingredients in bakery and pasta products. Food Research International. 2010;43:1975-80.

8. Paddon-Jones D, Short KR, Campbell WW, Volpi E, Wolfe RR. Role of dietary protein in the sarcopenia of aging. Am. J. Clin Nutr. 2008;87:1562-6.

9. Fujita H, Yamagami T, Ohsima K. Effects of an Ace-inhibitory agent, katsuobushi oligopeptide, in the spontaneously hypertensive rat and in borderline and mildly hypertensive subjects. Nutrition Research. 2001;21: 1149-58.

10. Rutherfurd-Markuvick KJ. Food proteins as a source of bioactive peptides with diverse functions. British Journal of Nutrition. 2012;108:149-57.

11. Larsen R, Eilertsen K-E, Elvevoll EO. Health benefits of marine foods and ingredients. Biotechnology Advances. 2011;29:508-18.

12. Rositawati LA, Taslim CM, Soetrisnanto D. Rekristalisasi Garam Rakyat dari Daerah Demak untuk Mencapai SNI Garam Industri. Jurnal Teknologi Kimia dan Industri. 2013:2:217-25.

13. Lempang M, Mangopang AD. Efektivitas Nira Aren Sebagai Bahan Pengembang Adonan Roti. Jurnal Penelitian Kehutanan Wallacea. 2012;1:2635

14. Lempang M. Pohon Aren dan Manfaat Produksinya. Info Teknis EBONI. 2012; 9:37-54.

15. Elegado, F. B., Colegio, S. M., Lim, V. M., Gervasio, A. T., Perez, M. T., Balolong, M. P., et al. (2016). Ethnic fermented foods of the Philippines with reference to lactic acid bacteria and yeasts. Ethnic Fermented Foods and Alcoholic, 323-340.

16. Masdarini L. Manfaat dan Keamanan Makanan Fermentasi untuk Kesehatan (Tinjauan dari Aspek IImu Pangan). JPTK, UNDIKSHA. 2011;8:53-8.

\section{Publisher's Note}

Springer Nature remains neutral with regard to jurisdictional claims in published maps and institutional affiliations.
Ready to submit your research? Choose BMC and benefit from:

- fast, convenient online submission

- thorough peer review by experienced researchers in your field

- rapid publication on acceptance

- support for research data, including large and complex data types

- gold Open Access which fosters wider collaboration and increased citations

- maximum visibility for your research: over $100 \mathrm{M}$ website views per year

At $B M C$, research is always in progress.

Learn more biomedcentral.com/submissions 